\author{
Halyna LITIKOVA, \\ orcid.org/0000-0003-2376-0734 \\ Assistant at the English Language Department for Maritime Officers (Abridged Programme) \\ Kherson State Maritime Academy \\ (Kherson,Ukraine) galitik.va@gmail.com
}

\title{
LINGUISTIC PECULIARS OF DISCOURSE IN MULTILINGUAL MARITIME CREW
}

The article considers the appropriateness of multilingual maritime crew discourse linguistic peculiars study, taking into account, that motley and bright the international maritime industry exists nowadays thanks to the English language which has become the lingua franca of the seas. Moreover, in compliance with the International Convention on Standards of Training, Certification and Watchkeeping for Seafarers $(1978,1995)$ and its Manila amendments (2010) English has already become the working language on all ships.

Though the English language has become a tool which maintains the discourse of multilingual maritime crew members with different non-English speaking background, cultural, religion, mentality features, even the use of coded phrases from the SMCP (Standard Maritime Communication Phrases) can't fully protect from so many emergencies and averages happening at sea, because of misunderstanding as a consequence of insufficient knowing of different native languages linguistic peculiars emerging in common-English-language on board and external communication.

Nowadays exists a great number of different studies in the fields of lingua franca communication discourse, environmental discourse, international and intercultural discourse on board, etc., but there haven't yet been conducted a holistic research of linguistic destructors in multinational lingua franca communication aboard.

The author makes analysis of the most spread non-English native languages on board (Filipino, Indonesian, Chinese), linguistic background of which destruct and misinterpret understanding of lingua franca discourse and may lead to human-element accidents at sea. She asserts, as English is non-native language to the most of seafarers: they have different accents, way of speaking, pitch, tone, vocabulary and their style of communication is also different, - there in crewing agencies must be provided a certain training in order to familiarize crewmembers with full set of knowledge about linguistic, intonation peculiars, cultural-mentality authentic features of future crew multilingual members in order to make lingua franca discourse not only challenging, but successful in order to make cross-cultural communication onboard not only difficult, but cognitive.

Key words: lingua franca, linguistic peculiars, discourse, multilingual maritime crew.

Галина ЛІТІКОВА, orcid.org/0000-0003-2376-0734 асистент кафедри англійської мови з підготовки морських фахівиів за скороченою програмою Херсонської державної морської академії (Херсон, Україна) galitik.va@gmail.com

\section{ЛІНГВІСТИЧНІ ОСОБЛИВОСТІ ДИСКУРСУ В БАГАТОМОВНОМУ МОРСЬКОМУ ЕКІПАЖІ}

У статті розглядається доиільність вивчення лінгвістичних особливостей багатомовного морського екіпажу, беручи до уваги, щуо строката і яскрава міжнародна морська промисловість існує сьогодні саме завдяки англійській мові, яка стала в иій галузі мовою мов. Крім того, відповідно до Міжнародної конвенції про стандарти підготовки, сертифікації та вахти моряків (1978, 1995) і Манільських поправок (2010), англійська вже стала робочою мовою на всіх суднах.

Англійська мова, безперечно, стала інструментом підтримки й реалізацї дискурсу в багатомовних морських екіпажах з різнорідним неангломовним походженням, культурними, релігійними, ментальними особливостями членів екіпажів, але навіть використання стандартних фраз англійською мовою з SMCP (Standard Maritime Coтmипісаtion Phrases) не може повністю уберегти суднові екіпажі від значної кількості надзвичайних ситуацій, щчо трапляються в морі через недостатнє розуміння того впливу, який спричиняють лінгвістичні особливості різних рідних мов на морську англійську мову загального вжитку на борту та поза його межами.

Сьогодні існує велика кількість різних розвідок у галузі комунікативного дискурсу лінгва франка, екологічного дискурсу, міжнародного та міжкультурного дискурсу на борту тощь, але досі не проводилося иілісного дослідження лінгвістичних деструкторів багатонаціональної комунікачії англійською лінгва франка мовою.

Автор робить аналіз найбільш розповсюджених неанглійських рідних мов на судні (філіппінська, індонезійська, китайська), лінгвістичні особливості яких руйнівно впливають на трактування дискурсу лінгва франка, 
спотворюють його й можуть призвести до аварій у морі з вини членів екіпажу. Щоб змінити дискурс англійської лінгва франка на судні з непростої справи на успішну, щэоб зробити міжкультурне спілкування на борту не лише важкуватим, а й пізнавальним, автор уважає, щуо в крюїнгових агентствах має постійно проводитися ознайомлення майбутніх членів морського екіпажу з лінгвістичними особливостями рідних мов представників тих національностей, із якими їм належатиме співпрацювати на судні.

Ключові слова: лінгва франка, мовні особливості, дискурс, багатомовна морська команда.

The statement of the issue. Life at sea - is an outstanding and endless area for discourses and researches focused on the purposes: to relieve life of seamen, deepen their already attained knowledge, investigate extremely new due to the fast life pace modifications of everything in the world and, eventually, apply all necessary on board, implementations to keep the shipping business go.

So motley and bright the international maritime industry exists nowadays thanks to the English language which has become the lingua franca of the seas. This fact enabled people of numerous nationalities communicate on board wherever language barriers exist. Thus the English language has become a tool which maintains the discourse of multilingual maritime crew members with different non-English speaking background, cultural, religion, mentality features. Even the use of coded phrases from the SMCP (Standard Maritime Communication Phrases) can't fully protect from so many emergencies and averages happening at sea, because of misunderstanding as a consequence of insufficient knowing of different native languages linguistic peculiars emerging in commonEnglish-language communication on board.

According to Macedonian researcher Tores Evangelos from Merchant Marine Academy and her work "Language barriers and miscommunication as a cause of maritime accidents" approximately $96 \%$ of the marine accidents were caused by the human factor: $38 \%$ errors in situation assessment, $17 \%$ psychic failing, $5 \%$ improper operation of instruments, $40 \%$ communication related factors, $12 \%$ can be attributed to on-board communication and $88 \%$ to external communication. (Tores, ...:25) She notified that the most difficult communication problems take place between ship and shore under critical conditions, in close and congested circumstances, when there is little time or space to rectify initial misunderstanding in passing orders between different language speakers on a vessel and during emergencies. (Tores, .... 5) Also were identified the circumstances in which linguistic misunderstandings occurred: 1. Maneuvering the vessel under pilotage, 2. External communication: ship to shore and ship to ship, 3. Inability to read instructions, 4. Cultural diversity, 5. In emergency situations. (Tores, ...: 10).

The analysis of relevant research. In order to make an attempt to determine the usefulness of lin- guistic peculiars of shipboard multilingual discourse consideration we've carried out a research of the last publications in the fields of discourse study: linguistic nature of discourse (Teun van Dijk, 1985); discourse of language acquisition process (Stephen Krashen, 1982); discourse of lingua franca communication (Henry and Tator, 2002); context-dependent nature of discourse (Bloor and Bloor, 2013); environmental discourse (Baker and Ellece, 2013); overarching nature of discourse (Renkema, 2004). Also were studied sources about international and intercultural discourse on board a vessel of Ana Bocanegra-Valle (2010), Mileca Dzeverdanovich-Pejovic (2013), Ulf Schiever (2008). Due to unremitting number of accidents in maritime sphere contributed by misunderstanding when speaking through VHF radio and in everyday face-to-face communication these studies approved growing concern to multilingual background of lingua franca non-native English speakers on board.

Though generally emphasized poor or careless use of basic Maritime English units and phrases, its grief consequences for shipping industry and maritime environment, there haven't yet been conducted a holistic research of linguistic destructors in multinational lingua franca communication aboard.

The purpose of the article. The paper is intended to provide an overview of those linguistic peculiars of the most spread non-English speakers' background which destruct and misinterpret understanding of lingua franca discourse and may lead to humanelement accidents at sea. Therefore the peripheral issues to be considered are: 1 . to determine the most frequently employed in shipping industry nations; 2. to deduce definition of multi-linguistic maritime discourse; 3 . to review linguistic peculiars of three the most spread non-English speakers background which may cause misunderstanding and cause human-element accidents.

The body of the research. During the study tour of Western Michigan University students to Korea, one of the high officials from Korean shipping industry when doing his presentation apologized for his poor English. He asked the students to name the number of English language kinds that exist now in the world, and students replied: "UK English", "subcontinental English", "US English", "combined English", etc. He added: "There is another type of English and that 
is - broken English". English is non-native language to the most of seafarers. They have different accents, way of speaking, pitch, tone, vocabulary and their style is also different. That is why cross-cultural communication becomes difficult (Rehman, 2007: 29).

In 2012 International Journal of New Trends in Arts, Sports \& Science Education published the investigation of "Seafarers Market". The biggest amount of crew members among officers and ratings were occupied in this list by Filipino nationality (International Journal of New Trends, 2012: 34).

At the beginning of year 2020, web resource "Maritime Zone" used ICS (International Chamber of Shipping) data, where were mentioned 5 main crewing countries (supplying both officers and ratings) in the world: The Philippines (the leading supplier of ratings in the world); China (the biggest provider of officers in the world and $2^{\text {nd }}$ by ratings supply); Indonesia; the Russian Federation; Ukraine.

It's quite fair to use lingua franca language even when there two or more nationalities representatives work together on a ship. Maritime English as lingua franca language on a ship was officially adopted in 1978 with the year of STCW (International Convention on Standards of Training, Certification and Watchkeeping for Seafarers) entry into force. Since then Maritime English became the only working language on board of any type of vessel.

P. Kumar in his article "Communication among multinational and multicultural crew on board a ship" noted that $67 \%$ of the ships have crews from various nations and are multilingual (Kumar, 2018).

I.e. these $67 \%$ ship crews are involuntarily involved into lingua franca communication and each time they participate in multinational interaction. In terms of sociolinguistics interaction of the people with the use of written, vocal, sign language or any semiotic system for sentences, phrases, speech production. The author L. Posey asserts that discourse is a huge part of everyday communication among people in which both explicit and implicit communication-based goals are achieved (Posey L.).

In the opinion of Henry Frances and Carol Tator discourse is the way in which language is used socially to convey broad meanings and bridge personal and social worlds of people. (Frances, Tator, 2002).

As more attentive the speaker is to context of conversation and background information or knowledge concerning co-speaker, the more successful, in the opinion of Bloor and Bloor, communication will be (Bloor and Bloor, 2013).

Also Herbert Clark makes common ground of interaction a central notion of his study about discourse as a joint activity of people. He considers that all sums of knowledge, beliefs and suppositions of communicative process participants must seek for common ground of interaction finding to build up successful communication. The scholar compares business in use with the business transaction, paddling together in a canoe, playing cards or performing music in an orchestra (Clark, 2014).

A research of discourse structure was made by Barbara J. Grosz and Candace L. Sinder. They assure that three structural constituents interact in discourse structure: linguistic peculiars, intentions and attention. In their opinion discourse is impossible without any of them (Grosz Barbara, Sidner, 1986).

As more cohesion among all these discourse elements, as more successful franca lingual communication will be. Thus we may conclude that multilingual maritime discourse is a set of knowledge about native language linguistic background, intonation peculiars, cultural and mentality authentic features.

Taking into account the fact that employing crews from many nation has huge problems connected with communication barriers, misunderstanding and sounding language confusing, culture and religion differences, any of which may lead to safety risks onboard, there must be a certain training in order to familiarize crewmembers with full set of knowledge about background knowledge of native language linguistic, intonation peculiars, cultural and mentality authentic features in order to make lingua franca discourse not only challenging, but successful.

"Every act of communication is a miracle of translation,"- said once a multiple Hugo award-winning American author of science fiction and fantasy Ken Liu (Learn Filipino - Level 1). Each person at least once in his life had an experience when he was talking to somebody in his native language but there were problems of getting rid with a finding the compromise. So what then should we say concerning the multicultural communication on board, especially, when it deals with a stressful environment, which is featured with a lack of civilization around? Here the words of famous British novelist and critic Paul Bailey may be found accurate and valuable, if we talk about the necessity of one common for everybody's use language on board of each ship in order to make sure you communicate your idea quickly and keep it straight to the point, even when you speak to that most spread on board Philippino, Indonesian, Chinese nationality representatives.

Speaking about the leader of the "Seafarers Market" list, we can't neglect that Philippines country has 170 native Filipino languages. Nevertheless nowadays Filipino laws and court decisions, with extremely rare exceptions, are written solely in English. English is 
also used in higher education, religious affairs, print and broadcast media, and business. Most educated Filipinos are bilinguals and speak English as one of their languages. For highly technical subjects such as nursing, medicine, computing and calculus, English is the preferred medium for textbooks, communication, etc. Very few would prefer highly technical books in either Filipino or the regional language. But except wide English language background, Spanish was the official language of the country for more than three centuries under Spanish colonial rule, and became the lingua franca of the Philippines in the $19^{\text {th }}$ and early $20^{\text {th }}$ centuries. Such fact may determine actual effects on modern Filipino English language.

There are thousands of Spanish loanwords in 170 native Filipino languages, and Spanish orthography has influenced the spelling system used for writing most of these languages. There are approximately 4.000 Spanish words - between $20 \%$ and $33 \%$ of Tagalog words. Tagalog is the national language of the Philippines, one of two official languages alongside English.

Filipino speakers have what we call "Filipino accent", which can be difficult to understand by some native English speakers. English teachers have noticed such the most striking errors that Filipino students usually make: interchanging or mix up several consonants and vowels. The most common examples are:

1. Substitution the $/ \mathrm{p} /$ in a word for an $/ \mathrm{f} /$ and the $/ \mathrm{v} /$ and $/ \mathrm{b} /$ sounds. It's interesting to take into account that in Spanish, the letters "B" and "V" sound more similar than they do in English. The Spanish "V" is pronounced similarly to " $\mathrm{B}$ ". In this case Spanish influence on Filipino pronunciation is quite noticeable, especially when we will look at English and Filipino pronunciation of the same English words:

Varnish $=[$ 'barnif]; Fun $=[$ 'pen $]$ or ['pan]; Very $=[$ 'beri] or ['bejri]; Victor $=[$ bik' tor $]$.

2. Th-stopping, which means quite often substitution a $/ \mathrm{th} /$ sound with either a $/ \mathrm{t} /$ or a $/ \mathrm{d} /$. The dental fricatives $/ \theta /$ and $/ \delta /$ become the alveolar stop consonants $/ \mathrm{t} /$ and $/ \mathrm{d} /$, respectively. There are some examples:

/th/ sound substitutes with $/ \mathrm{d} /$ sound: That $=[\mathrm{d}$ æt $]$; This $=[\mathrm{dis}]$; There $=[\mathrm{der}]$; Them $=[\mathrm{dem}]$; Breathe $=$ [bri:d];

/th/ sound substitutes with / $/$ / sound: Beneath $=$ [bı'ni:t]; Death = [det $]$;

$/ \mathrm{d} /$ sound substitutes with $/ \mathrm{t} /$ sound: Bread $=[\mathrm{bret}]$; Deep $=[$ ti:p $]$.

3. Coarsening of $/ r /$ sound. In Filipino English, pronunciation is more likely to hear how the tongue mostly rolls against the palate (roof of a mouth) to make the sound. It is very similar to the Spanish $/ \mathrm{r} /$ sound. Because of this / $r$ / sounds ruder than in English native pronunciation.

4. Interchanging /a/ sound, which is usual sounds as $/ æ, \Lambda, \mathrm{a} /$. In this case, it is pronounced as central vowel [ä] and [e]. In the standard dialect, the open front [a] may be pronounced as an allophone of $/ æ /$. Examples: Family $=[$ 'pemili $]$ or ['pamili]; Promise $=$ ['prä:mıs]; Accent $=$ ['äksent].

A remarkable experience of Philippino future seafarers English language training was described by Caroline W. Dacwag from Philippines in her work "Negotiation of Meaning in a Multilingual Crew: The Experience of MAAP Cadets". She described how Filipino cadets of the Maritime Academy of Asia and the Pacific (MAAP) were taught to build up their strategy for better understanding the crewmates with English mostly as their second or foreign language. They were listening to audio records and watched conversations with Indian English, Ukrainian and other nationalities crew members speaking English. They also were concerned to linguistic peculiars of non-native English speaker and their influence to multilingual communicative discourse on board (Negotiation of Meaning, 2017: 12).

The second biggest supplier of seamen employees is China. In this case, it is necessary to realize that Chinese is a tonal language, with the change in tone altering a word's meaning. Mostly the English language intonation happens at the phrasal level. Chinese English speakers have a tendency to apply Chinese intonation patterns when speaking English. This leaves native English speakers confused - especially if the meaning of a phrase can be altered using intonation. As Chinese speakers are used to their native intonation, they should just remember that intonation is normally applied to the entire phrase, and not any individual word. There are few major tendencies, which usually occur while listening Chinese English speaker:

1. Single syllable Chinese words. Most words in Chinese language are single syllable, but not in English. Because of this, native Chinese speakers attempt to separate English words, rather than connecting them smoothly. In English, the words that are spoken have an effect on each other and are not always pronounced separately with a pause in the middle. There are few examples among main areas of connecting speech:

"Most common" - "Moscommon" (assimilation);

"I have to" - "I haf to" (elision);

"I just woke up" - "I just wokup" (linking).

2. English vowels. The fact is that Chinese has fewer vowel sounds than English, which means that native Chinese speakers must learn how to position 
their mouth and tongue in new and different ways when attempting to pronounce English vowels. Such confusions commonly happen:

Short "I" with Short "E", (/I/ vs. /i/): "Fit" with. "Feet";

Short "E" with Short "A", (/e/ vs. /æ/): "Bed" with "Bad".

In Chinese pronunciation, long and short vowels can be used interchangeably without changing the meaning of the word. Not so in English.

3. Modified English consonants. Some consonants that appear regularly in the English language aren't used at all in Chinese. When trying to produce these sounds, native Chinese speakers will often inadvertently modify them slightly. Chinese speakers often either drop ending consonants completely, or break them up by inserting a vowel sound. For instance:

- Replacement of the $/ \mathrm{r} /$ and $/ \mathrm{v} /$ sounds with $/ \mathrm{b} /$ or /w/. "Very" becomes "Wawy"; Replacement of the /th/ sound with /s/ sound. "Mouth" becomes "Mouse"; "Throne" becomes "Srone";

- Producing an extra syllables, as a result of tending to stress the last sound of a word. "And" becomes "An-duh."

Indonesian, as it is known today, was heavily influenced by several languages due to historical ties with other nations. Dutch made the highest contribution to the language, especially in vocabulary due to the Dutch's colonization for over three centuries, from the $16^{\text {th }}$ century until the mid- $20^{\text {th }}$ century.

As a modern variety of Malay, Indonesian has been influenced by other languages, including Dutch, English, Arabic, Chinese, Portuguese, Sanskrit, Tamil, Hindi, and Persian. It is estimated that there are some 750 Sanskrit loanwords in modern Indonesian, 1,000 Arabic loans, some of Persian and Hebrew origin, some 125 words of Portuguese, some of Spanish and Italian origin, and 10,000 loanwords from Dutch. Besides, before the standardization of the language, many Indonesian words follow standard Dutch alphabet and pronunciation. Nevertheless, Indonesian English speaker may face with other English speaking difficulties:

1. Opposite order. Adjective phrases in the two languages are in opposite order. In English, the adjective comes before the noun, but in Indonesian, the noun is mentioned first: "Red car".

2. Passive voice prevalence. While the passive voice is frequently used in Indonesian, English sentences are stronger in the active form, especially when the focus is on the object. Example: "The last slice of cake was eaten by my brother" seems more correct in eyes of Indonesian speakers than when it's active: "My brother at the last slice of cake".
3. Not existing sounds. When Indonesian speakers begin learning English, they have to face hard reality that this language is not written phonetically just like Indonesian and some English sounds do not exist in Indonesian language so arise such tendency as:

- Tending to replace Interdental sounds $/ \theta /$ and $/ ð /$ sounds with alveolar sound $/ d /$. Sounds $/ \theta /$ (voiceless) and $/ ð /$ (voiced) related to pronouncing "th". Since these two sounds do not exist in Indonesian, it is extremely difficult for the Indonesian learners of English to pronounce "th". For example: "They" is pronounced /dei/ instead of /der/ (Kaharuddin, 2018).

- Representing letter "c" with a phoneme /c/: "Cook" is pronounced/cuk/ instead of /kok/.

4. Same verb form. In Indonesian language, grammar rules are simpler rather than in English, because it has 16 different tenses. Indonesian uses the same verb for past, present and future situations. That's why the problems with defining time period in speech of Indonesian English speakers may occurs.

Conclusions. The investigation of linguistic peculiars of three the most common on board nationalities, carried out in this article will help to find out the ultimate "ramp" of common English language, suggesting only particular specific terminology for the ship use, advising the shortest way to get a success in unifying numerous language backgrounds and gathering crew mates from all over the world with the only goal - to keep and maintain safety, which means to keep and maintain human lives at sea. Among them are those, which should be kept in mind when seafarer is lanning to work on a ship with multilingual crew, having Phillipino, Chinese or Indonesian crew members on board.

1. Filipino English linguistic peculiars include:

a) substitution of sounds in words:

$-/ \mathrm{p} /$ for $/ \mathrm{f} /$;

$-/ \mathrm{v} /$ for $/ \mathrm{b} /$;

- $/$ th/ for $/ \mathrm{d} /$ and for $/ \mathrm{t} /$;

- open front [a] for an allophone of $/ \mathfrak{x} /$

b) coarsening of $/ \mathrm{r} /$ sound as in Spanish.

2. Chinese English linguistic peculiars include:

a) single syllable separation of English words, rather than connecting them smoothly;

b) carry-over of Chinese interchangeability of long and short without changing the meaning of the word to English vocabulary;

c) dropping ending consonants completely, or break them up by inserting a vowel sound.

3. Indonesian English linguistic peculiars include:

a) opposite order of words in phrases;

b) Passive voice prevalence;

c) Use of not existing sounds;

d) preference of the same verb form in all tenses. 
These knowledge will help to take away verbal and cultural barriers, turn challenging internal and external multilingual communication at sea into efficient and to avoid possible cultural clashes in the multicultural context. As some individuals or nations are by its nature language-sensitive must be borne in mind that these knowledge will help to overcome possible existence of cultural, religious, ideological or political reasons for an aversion to English. Together with the Standard Maritime Communication Phrases (SMCP) these knowledge will eliminate misunderstanding, resistance to the English language use and adjust its overwhelming acceptance as the common means of communication on board.

\section{BIBLIOGRAPHY}

1. Baker P., Sibonile E. Key Terms in Discourse Analysis. $1^{\text {st }}$ ed., Bloomsbury Academic, 2013. 240 p.

2. Bloor M., Bloor T. Practice of Critical Discourse Analysis : An Introduction. Routledge, 2013. 216 p.

3. Bocanegra-Valle A. The Language of Seafaring: Standardized Conventions and Discursive Features in Speech Communication / Servicio de Publicaciones. Universidad de Murcia. All rights reserved. IJES. 2001. Vol. 11 (1). P. $35-53$. URL: https://www.researchgate.net/publication/259735026_The_Language_of_Seafaring_Standardized_Conventions_and_ Discursive_Features_in_Speech_Communications [in English].

4. Clark H. H. Spontaneous Discourse. In V. Ferreira, M. Goldrick, and M. Miazzo (Eds.) Oxford Handbook of Language Production. Oxford : Oxford University Press, 2014.

5. Dzeverdanovich-Pejovic M. Discourse of VHF Communication at Sea and the Intercultural Aspect. International Journal for Traffic and Transport Engineering. 2013. 3(4). P. 377-396.

6. Frances H., Tator C. Discourses of Domination: Racial Bias in the Canadian English-Language Press. University of Toronto Press. 2002. 291 p.

7. Grosz Barbara J., Sidner C. Attention, Intentions, And The Structure Of Discourse Computational Linguistics. 1986. Volume 12. Number 3. P. 175-204. URL: https://www.researchgate.net/publication/2481502_Attention_Intentions_And_ The Structure Of Discourse [in English].

8. Intelligence Beyond the Horizon. Gain Control Over the Risk Ahead. URL: https://maritime-zone.com/en/news/view/ salary-gap-between-nationalities-in-maritime-industry [in English].

9. International Journal of New Trends in Arts, Sports \& Science Education. 2012. Volume 1. Issue 3. 143 p. URL: http://www.ijonte.org/FileUpload/ks63207/File/2012.1.complete.pdf [in English].

10. Kaharuddin A. English Phonetics for Indonesian Learners of English (An Essential Guide to Natural English Pronuncitation). 2018. URL: https://www.researchgate.net/publication/341774866_English_Phonetics_for_Indonesian_ Learners of English An Essential Guide to Natural English Pronuncitation.

11. Kumar P. Communication Among Multinational and Multi-Cultural Crew on Board a Ship. International Journal of Civil Engineering and Technology (IJCIET). Volume 9. Issue 12. December 2018. P. 1189-1195. URL: http://www.iaeme. com/MasterAdmin/Journal_uploads/IJCIET/VOLUME_9_ISSUE_12/IJCIET_09_12_121.pdf [in English].

12. Krashen, Stephen. (1982) Principles and practice in second language acquisition. New York : Pergamon Press, 1982. Review by: Karl J. Krahnke TESOL Quarterly. Vol. 17. № 2 (Jun., 1983). P. 300-305. Published By : Teachers of English to Speakers of Other Languages, Inc. (TESOL). URL: https://www.jstor.org/stable/3586656?seq=1 [in English].

13. Learn Filipino - Level 1: Introduction to Filipino: Volume 1: Lessons 1-25, Spanish Pronunciation Similar to Filipino. URL: https://books.google.com.ua/books?id=3V0yDwAAQBAJ\&pg=PT34\&lpg=PT34\&dq=spanish+pronunciation+sim ilar+to+filipino\&source $=$ bl\&ots $=$ PD76z LAe\&sig $=$ ACfU3U0wgoaWylKU9W90yXVT2yhkltes0A\&hl=ru\&sa $=$ X\&ve $\mathrm{d}=2$ ahUKEwjSquXWn7HuAhXcBhAIHf8XDPcQ6AEwFHoECBkQAg\#v=onepage\&q=spanish\%20pronunciation\%20similar\%20to\%20filipino\&f=false [in English].

14. Negotiation of Meaning in a Multilingual Crew: The Experience of MAAP Cadets, Caroline W. Dacwag (Philippines), International Maritime English Conference (23-27 October 2017). Korea Institute of Maritime and Fisheries Technology Busan, Republic of Korea.

15. Rehman, Altaf, Ur. Communication Skills and Cultural Awareness - Model Course, World Maritime University, 2007. 137 p. URL: https://commons.wmu.se/cgi/viewcontent.cgi?article=1212\&context=all_dissertations [in English].

16. Renkema J. Introduction to Discourse Studies. John Benjamins, 2004. 363 p.

17. Pronunciation Problems of Students in the Philippines. URL: https://www.teflcourse.net/blog/pronunciationproblems-of-students-in-the-philippines/.

18. Schiever, Ulf. (2008) Maritime Communication in an International and Intercultural Discourse / Dip. App. Sc. (Australian Maritime College), Med (University of Tasmania), 2008. 180 p. URL: https://core.ac.uk/download/pdf/33333852. pdf [in English].

19. Tores Evangelos. Language Barriers and Miscommunication as a Cause of Marine Accidents, Merchant Marine Academy of Macedonia. 90 p. URL: https://maredu.hcg.gr/modules/document/file.php/MAK265/Dissertations\%20in\%20 English/Language $\% 20$ barriers $\% 20$ and $\% 20$ miscommunication $\% 20 a s \% 20 a \% 20$ cause $\% 20$ for $\% 20$ marine $\% 20$ accidents.pdf [in English].

20. Van Dijk, Teun Adrianus. (1985) Handbook of Discourse Analysis. Academic, 1985. 228 p. 


\section{REFERENCES}

1. Baker, Paul and Sibonile, Ellece. (2013) Key Terms in Discourse Analysis. $1^{\text {st }}$ ed., Bloomsbury Academic, 2013. 240 p.

2. Bloor, Meriel, and Bloor, Thomas. (2013) Practice of Critical Discourse Analysis: An Introduction. Routledge, 2013. $216 \mathrm{p}$.

3. Bocanegra-Valle, Ana. (2010) The Language of Seafaring: Standardized Conventions and Discursive Features in Speech Communication / Servicio de Publicaciones. Universidad de Murcia. All rights reserved. IJES, vol. 11 (1), 2011 , pp. $35-53$. URL: https://www.researchgate.net/publication/259735026_The_Language_of_Seafaring_Standardized_Conventions_and_ Discursive_Features_in_Speech_Communications [in English].

4. Clark , H. H. (2014) Spontaneous Discourse. In V. Ferreira, M. Goldrick, and M. Miazzo (Eds.) Oxford Handbook of Language Production. Oxford: Oxford University Press.

5. Dzeverdanovich-Pejovic, Milena. (2013) Discourse of VHF Communication at Sea and the Intercultural Aspect / International Journal for Traffic and Transport Engineering, 2013. 3(4): 377 - 396.

6. Frances, Henry and Tator, Carol. (2002). Discourses of Domination: Racial Bias in the Canadian English-Language Press. University of Toronto Press. 2002. 291 p.

7. Grosz Barbara J., Sidner C. (1986) Attention, Intentions, And The Structure Of Discourse Computational Linguistics, Volume 12, Number 3, luly-September 1986. pp. 175-204. URL: https://www.researchgate.net/publication/2481502_Attention_Intentions_And_The_Structure_Of_Discourse [in English].

8. Intelligence Beyond the Horizon. Gain Control Over the Risk Ahead. URL: https://maritime-zone.com/en/news/view/ salary-gap-between-nationalities-in-maritime-industry [in English].

9. International Journal of New Trends in Arts, Sports \& Science Education - 2012, volume 1, issue 3. 143 p. URL: http://www.ijonte.org/FileUpload/ks63207/File/2012.1.complete.pdf [in English].

10. Kaharuddin, A. (2018) English Phonetics for Indonesian Learners of English (An Essential Guide to Natural English Pronuncitation). URL: https://www.researchgate.net/publication/341774866_English_Phonetics_for_Indonesian_Learners_ of English An Essential Guide to Natural English Pronuncitation

11. Kumar, P. (2018) Communication Among Multinational and Multi-Cultural Crew on Board a Ship / International Journal of Civil Engineering and Technology (IJCIET), Volume 9, Issue 12, December 2018, pp. 1189-1195. URL: http:// www.iaeme.com/MasterAdmin/Journal uploads/IJCIET/VOLUME 9 ISSUE 12/IJCIET 09 12 121.pdf [in English].

12. Krashen, Stephen. (1982) Principles and practice in second language acquisition. New Y̌rk: Pergamon Press, 1982. / Review by: Karl J. Krahnke TESOL Quarterly. Vol. 17. No. 2 (Jun., 1983). Pp. 300-305. Published By: Teachers of English to Speakers of Other Languages, Inc. (TESOL). URL: https://www.jstor.org/stable/3586656?seq=1[in English].

13. Learn Filipino - Level 1: Introduction to Filipino: Volume 1: Lessons 1-25, Spanish Pronunciation Similar to Filipino. URL: https://books.google.com.ua/books?id=3V0yDwAAQBAJ\&pg=PT34\&lpg=PT34\&dq=spanish+pronunciation + similar+to+filipino\&source=bl\&ots $=$ PD76z_LAe\&sig $=$ ACfU3U0wgoaWylKU9W90yXVT2yhkltes0A\&hl=ru\&sa $=$ X\& ved=2ahUKEwjSquXWn7HuAhXcBhĀIHf8XDPPcQ6AEwFHoECBkQAg\#v=onepage\&q=spanish\%20pronunciation\%20similar\%20to\%20filipino\&f=false [in English].

14. Negotiation of Meaning in a Multilingual Crew: The Experience of MAAP Cadets, Caroline W. Dacwag (Philippines), International Maritime English Conference (23 - 27 October 2017). Korea Institute of Maritime and Fisheries Technology - Busan, Republic of Korea.

15. Rehman, Altaf, Ur. Communication Skills and Cultural Awareness - Model Course, World Maritime University, 2007. 137 p. URL: https://commons.wmu.se/cgi/viewcontent.cgi?article=1212\&context=all_dissertations [in English].

16. Renkema, Jan. (2004) Introduction to Discourse Studies. John Benjamins, 2004. 363 p.

17. Pronunciation Problems of Students in the Philippines. URL: https://www.teflcourse.net/blog/pronunciation-problems-of-students-in-the-philippines/

18. Schiever, Ulf. (2008) Maritime Communication in an International and Intercultural Discourse / Dip. App. Sc. (Australian Maritime College), Med (University of Tasmania), 2008. 180 p. URL: https://core.ac.uk/download/pdf/33333852.pdf [in English].

19. Tores Evangelos. Language Barriers and Miscommunication as a Cause of Marine Accidents, Merchant Marine Academy of Macedonia. 90 p. URL: https://maredu.hcg.gr/modules/document/file.php/MAK265/Dissertations $\% 20$ in $\% 20$ English/Language $\% 20$ barriers $\% 20$ and $\% 20$ miscommunication $\% 20$ as $\% 20 \mathrm{a} \% 20$ cause $\% 20$ for $\% 20$ marine $\% 20$ accidents.pdf [in English].

20. Van Dijk, Teun Adrianus. (1985) Handbook of Discourse Analysis. Academic, 1985. 228 p. 